Vol. 5 (1996): 475-483.

\title{
Yield reduction caused by a soil-borne disease of naked, dwarf, and conventional oat in Finland
}

\author{
Pirjo Peltonen-Sainio \\ Department of Plant Production, P.O. Box 27, FIN-00014 University of Helsinki, \\ Finland, email: pirjo.peltonen-sainio@helsinki.fi \\ Jari P.T. Valkonen \\ Department of Plant Production, P.O. Box 27, FIN-00014 University of Helsinki, Finland \\ Hilkka Koponen \\ Department of Plant Biology, P.O. Box 28, FIN-00014 University of Helsinki, Finland
}

\begin{abstract}
A severe disease occurred in the field plots of naked (cv. Salomon), dwarf (cv. Pal), and conventional oat (cvs. Jalostettu maatiainen and Salo) at the Viikki Experimental Farm of the University of Helsinki, Finland, in 1994 and 1995. Symptoms were expressed as grayish-brown necrotic areas on the lower leaves which killed plants from the seedling to heading stage, the effect being cultivar dependent. The proportion of plants killed contributed to the yield losses. The infection also resulted in less grains per panicle and lower weight of both panicle and vegetative above-ground biomass. From a total of 57 fungal isolates obtained from infected leaves, Fusarium culmorum (W.G.Sm.) Sacc. and $F$. sambucinum Fuck. dominated and subsequently caused infection (particularly foot and root rot) in oat in laboratory tests. These two Fusarium spp. were considered to be the primary causal agents of the symptoms observed in the field, although other pathogens may have been present. The disease was probably soil-borne. The results of this study suggested that the unusually dry and warm weather during late June and in July was the principal factor behind the severe disease outbreak.
\end{abstract}

Key words: Fusarium, grain yield, growth duration, pathogenicity, symptom severity, yield components

\section{Introduction}

Oat (Avena sativa L.) is affected by fewer diseases than barley (Hordeum vulgare L.) and wheat (Triticum aestivum L.) in northern growing conditions. The bird cherry-oat aphid (Rho- palosiphum padi L.) causes direct damage through feeding and transmits barley yellow dwarf virus (BYDV), causing occasional but severe yield losses (up to $40 \%$ ) in oat in Finland (Rautapää 1976, Peltonen-Sainio and Karjalainen 1990). Other aphid species (Metopolophium dirhodum Walk., Sitobion avenae F.) cause yield 


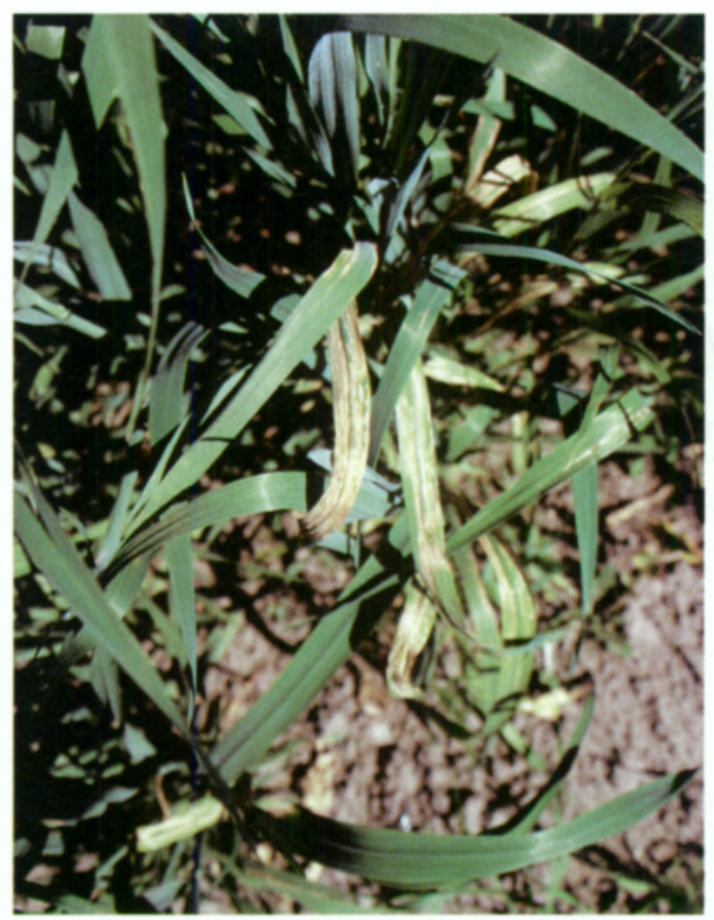

Fig. 1. Leaf symptoms in the dwarf oat cultivar Pal at preanthesis in 1994. (Photo Pirjo Peltonen-Sainio).

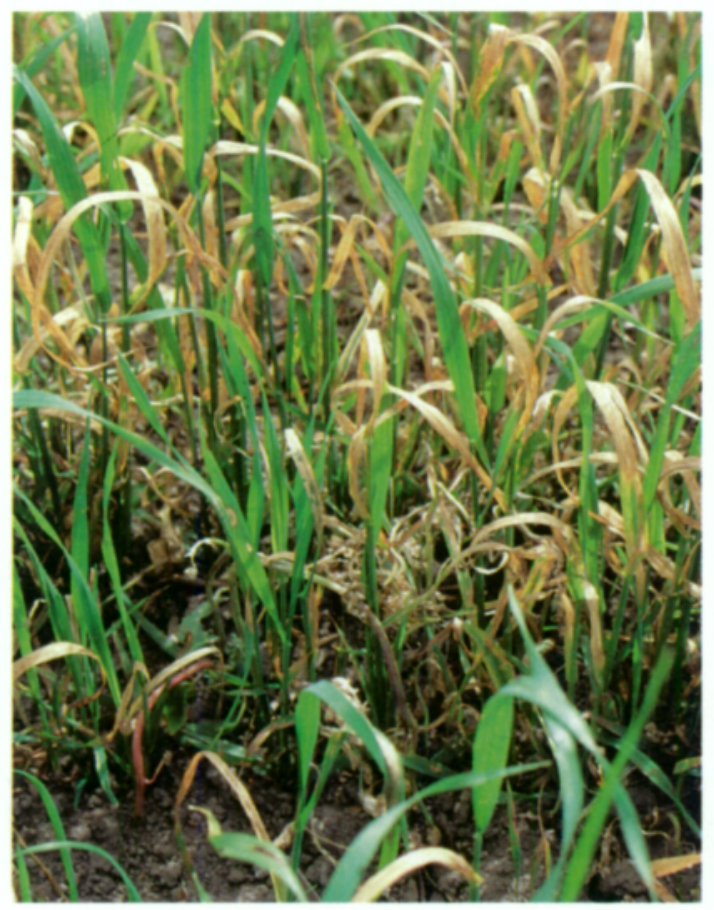

Fig. 3. Typical disease symptoms of survived plants at preanthesis in 1995. (Photo Pirjo Peltonen-Sainio).

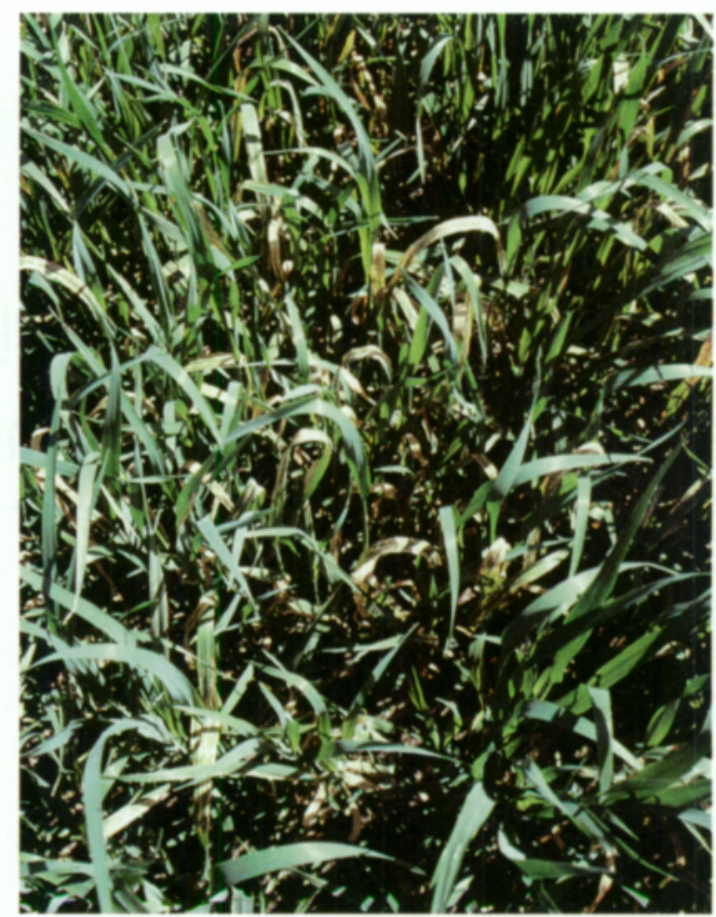

Fig. 2. Lower leaves of the diseased canopy in the naked oat cultivar Salomon in 1994. (Photo Pirjo Peltonen-Sainio).

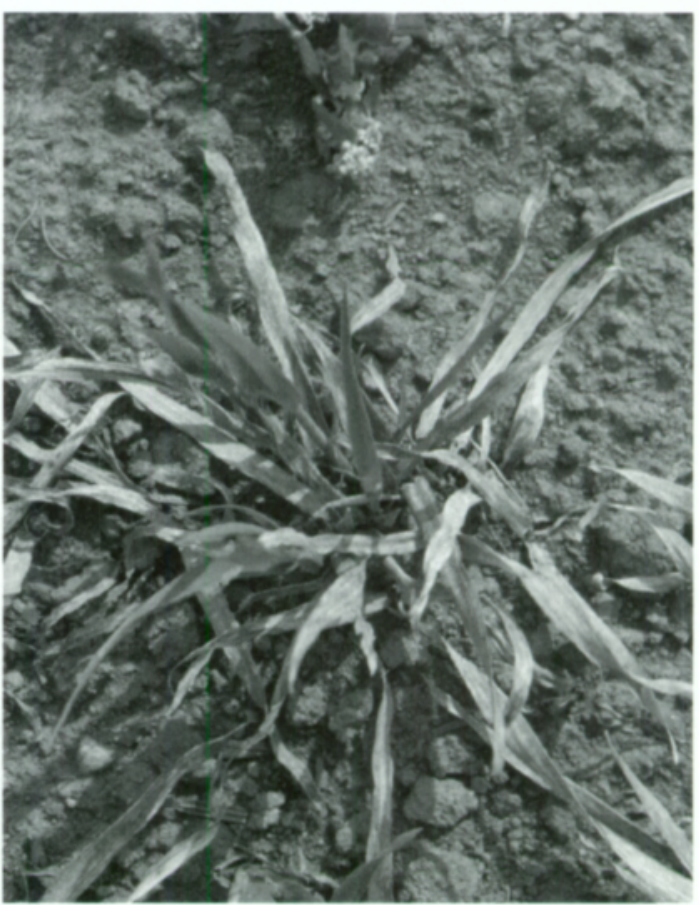

Fig. 4. Seedlings of the diseased dwarf oat cultivar Pal at the tillering stage in 1995. (Photo Pirjo Peltonen-Sainio). 
Vol. 5 (1996): 475-483.

Table 1. Monthly mean temperatures and precipitation during the growing seasons of 1994 and 1995 , and the long-term means (1961-1990) at the Kaisaniemi Meteorological Station, Helsinki.

\begin{tabular}{lrrrrrrrr}
\hline \multirow{2}{*}{ Month } & \multicolumn{3}{c}{ Mean temperature $\left({ }^{\circ} \mathrm{C}\right)$} & & \multicolumn{3}{c}{ Precipitation $(\mathrm{mm})$} \\
\cline { 2 - 3 } \cline { 7 - 9 } & 1994 & 1995 & Long-term & & 1994 & 1995 & Long-term \\
\hline April & 4.6 & 3.1 & 3.1 & & 64 & 22 & 37 \\
May & 8.8 & 8.6 & 9.7 & & 49 & 64 & 31 \\
June & 12.5 & 17.1 & 15.0 & & 57 & 31 & 41 \\
July & 19.8 & 15.7 & 17.0 & & 2 & 24 & 60 \\
August & 16.4 & 15.8 & 15.7 & & 67 & 49 & 74 \\
September & 12.0 & 11.1 & 11.1 & & 129 & 82 & 73 \\
\hline
\end{tabular}

reduction in oat mainly by transmitting BYDV. Disease epidemics are, however, rare in oat. Oat favors cool growing seasons and does not suffer particularly in acidic soils. For these reasons, oat is generally regarded as a healthy crop in Finland.

Pronounced foliar symptoms, growth reduction, and high mortality of plants occurred in a field experiment including various oat cultivars at the Viikki Experimental Farm, University of Helsinki, in 1994 and 1995 (Figs. 1-4). In both years, the weather conditions deviated from the long-term averages for late June/July when exceptionally long and severe droughts with high temperatures occurred during grain-filling of oat (Table 1). The Minnesota-adapted dwarf cv. Pal and the naked oat cv. Salomon were particularly affected. This paper describes the changes in yield formation and describes a preliminary survey for the identification of the causal agent of the disease symptoms.

\section{Material and methods}

\section{Field experiments}

A field experiment including five oat cultivars was severely affected by a disease at Viikki Experimental Farm University of Helsinki, Finland $\left(60^{\circ} 13^{\prime} \mathrm{N}\right)$, in 1994 . The experiment was sown as a split-plot design with four replicates. $\mathrm{N}$ fertilizer application rates $\left(0\right.$ and $80 \mathrm{~kg} \mathrm{~N}^{-1}$ as $\mathrm{NH}_{4} \mathrm{NO}_{3}$ at sowing) were applied to main plots and oat cultivars were split across them. The following oat cultivars were included: Jalostettu maatiainen, a long-strawed landrace released in Finland in 1921; Virma and Salo, representing modern Finnish cultivars; Pal, a Minnesota-adapted dwarf cultivar; and Salomon, a naked oat cultivar. As the disease appeared unexpectedly and no control plot had been sown to study the effect of the disease, the morpho-physiological measurements from the infected experiment were compared with data obtained from non-infected field experiments which were 100 $\mathrm{m}$ distant from the infected area and included the same oat cultivars and similar $\mathrm{N}$ fertilizer application rates. In 1995, two experiments identical to the trial in 1994 were carried out in the same field. One experiment was sown in the same place in which the severe infection occurred in 1994. The control experiment was sown nearby and was supposed to be free of the disease. However, this trial was severely infected and only a few panicles with a few grains were found at the end of the growing season (Fig. 1). Therefore, no control was available in 1995.

Net plot size was $10 \mathrm{~m}^{2}(1.25 \times 8 \mathrm{~m})$ with $12.5 \mathrm{~cm}$ between rows. Seeding rate was 500 viable seeds $\mathrm{m}^{-2}$. In 1994, seeds were dressed prior to sowing with metoxyethyl- mercurychloride at $22.1 \mathrm{~g}$ a.i. $\mathrm{kg}^{-1}$, whereas in 1995 , seed dressing was omitted in order to increase the 


\section{AGRICULTURAL AND FOOD SCIENCE IN FINLAND}

\section{Peltonen-Sainio, P. et al. Yield reduction caused by a soil-borne disease of oat}

probability of disease development. Weeds were controlled with MCPA [(4-chloro-2-methylphenoxy) acetic acid] at $600 \mathrm{~g}$ a.i. ha- ${ }^{-1}$ and dichlor-

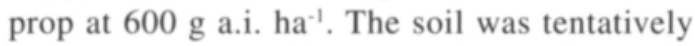
classified as clayey, illitic Oxyaquic Cryoboroll (M. Yli-Halla, personal communication).

Disease severity was monitored by recording the percentage of plants showing disease symptoms in each plot using a scale from 1 $(=0 \%)$ to $9(=100 \%)$ at intervals of $12.5 \%$. Additionally, the percentage of killed plants was recorded at late grain-filling in 1995. Grain was harvested and weighed $\left(\mathrm{kg} \mathrm{ha}^{-1}\right.$ calculated at $15 \%$ moisture), except from the control experiment which produced no measurable grain yield in 1995. Additionally, in 1994, the following morpho-physiological traits were measured from infected and control plots: 1) number of emerged seedlings $\mathrm{m}^{-2} ; 2$ ) number of panicles $\mathrm{m}^{-2} ; 3$ ) days from sowing to heading; 4) days from sowing to yellow ripeness; 5) length of grain-filling period (d); 6) plant height (cm); 7) phytomass $\left(\right.$ g plant $\left.^{-1}\right) ; 8$ ) vegetative phytomass $\left(\right.$ g plant $\left.^{-1}\right) ; 9$ ) total weight of grains per panicle (i.e., panicle weight, g); 10) harvest index (HI, i.e., panicle weight divided by phytomass, \%); 11) single grain weight $(\mathrm{mg}) ; 12)$ number of grains per panicle; 13) mean panicle-filling rate (PFR, mg panicle $^{-1}$ day $\left.^{-1}\right)$; and 14) mean grain-filling rate $\left(\right.$ GFR, mg grain ${ }^{-1}$ day $\left.^{-1}\right)$. Traits 7-14 were measured from 40 randomly sampled plants in each plot. Significance of differences in disease severity and percentage of killed plants between $\mathrm{N}$ fertilizer application rates and lines were established in the infected experiments of 1994 and 1995 using ANOVA (MSTAT Development Team 1989). The means for grain yield and morpho-physiological traits from infected plots were compared with those of the control plots in 1994.

\section{Pathogenicity tests}

Leaves with symptoms from different oat cultivars were collected from the field, surface-sterilized with $2 \%$ sodium hypochlorite for $2 \mathrm{~min}$ utes, rinsed twice with sterile water, and cut into sections $\left(1 \mathrm{~cm}^{2}\right)$ with a sterile scalpel. Leaf sections were placed on potato dextrose agar (PDA; Difco) in plastic Petri dishes ( $\varnothing 9 \mathrm{~cm})$ and incubated at $23-25^{\circ} \mathrm{C}$. Pure cultures of fungi were obtained by serial transfers of mycelia to fresh PDA plates. Identification of fungi was based on the method of Domsch et al. (1980a, 1980b). Fungi were grown on water agar until mycelia covered the plate and were then used for inoculation.

Pathogenicity of the fungal isolates from oat leaves was tested on the naked cv. Salomon and the dwarf cv. Pal using seeds which were harvested in 1994 from non-infected field plots. For pathogenicity tests, seeds were surface-sterilized by soaking in $70 \%$ ethanol for $1 \mathrm{~min}$, rinsed three times with sterile water and pre-germinated between moist filter papers overnight. After surface sterilization, the seeds were free of fungal contaminants based on incubation on PDA as described above.

Preliminary tests for pathogenicity were carried out by placing two pre-germinated seeds of Salomon on moist, sterile filter paper in a Petri dish. A plug of water agar with fungal mycelium was placed immediately adjacent to each seed. Two dishes were inoculated with each fungal isolate. Dishes were incubated in a growth chamber at $19 / 23^{\circ} \mathrm{C}$ (photoperiod $18 \mathrm{~h}, 90 \mu \mathrm{mol} \mathrm{s}{ }^{-1}$ $\mathrm{m}^{-2}$ ). Development of symptoms was observed up to 12 days after inoculation. Those fungi isolated from Salomon and $\mathrm{Pal}$ and shown to be pathogenic based on the preliminary tests, and one isolate of Fusarium culmorum obtained from the landrace oat cv. Jalostettu maatiainen grown next to the other two cultivars in the field, were selected for further pathogenicity tests in the glasshouse $\left(19 / 24^{\circ} \mathrm{C}\right.$, photoperiod extended to 18 $\mathrm{h}$ with the illumination of fluorescent lamps). All water agar with fungal mycelium from one Petri dish was mixed in a small volume of sterile water using a blender and was then mixed with ca. one liter of steam-sterilized peat soil in one pot. Two or three pre-germinated seeds of Salomon or Pal were sown in each pot at the day of inoculation of the soil. Four pots of each oat line were tested with each fungal isolate. Pots 
Vol. 5 (1996): 475-483.

Table 2. Disease severity, percentage of killed plants, and grain yields in 1994 and 1995.

\begin{tabular}{|c|c|c|c|c|c|}
\hline \multirow[b]{2}{*}{ Line } & & \multirow{2}{*}{$\begin{array}{c}1994 \\
\begin{array}{c}\text { Disease severity } \\
(\%)\end{array}\end{array}$} & \multicolumn{3}{|c|}{1995} \\
\hline & & & $\begin{array}{c}\text { Disease severity } \\
\text { in survived plants } \\
(\%)\end{array}$ & $\begin{array}{l}\text { Percentage of killed } \\
\text { plants } \\
(\%)\end{array}$ & $\begin{array}{c}\text { Grain yield } \\
\left(\mathrm{kg} \mathrm{ha}^{-1}\right)\end{array}$ \\
\hline Salomon & & 60 & 15 & 5 & 1520 \\
\hline Pal & & 15 & 0 & 65 & 1020 \\
\hline Virma & & 15 & 10 & 15 & 1580 \\
\hline Salo & & 30 & 20 & 15 & 1580 \\
\hline Landrace & & 20 & 5 & 15 & 1310 \\
\hline.$\pm \mathrm{E}$. & & 3 & 3 & 4 & 83 \\
\hline Source & df & 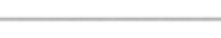 & $-\mathrm{P}>\mathrm{F}$ & 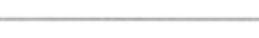 & \\
\hline Replication & 3 & ns & ns & ns & ns \\
\hline $\mathrm{N}$ rate & 1 & ns & ns & ns & ns \\
\hline Error & 3 & ns & ns & $\mathrm{ns}$ & ns \\
\hline Line & 4 & 0.001 & 0.051 & 0.001 & ns \\
\hline $\mathrm{N}$ rate $\mathrm{x}$ line & 4 & ns & ns & ns & ns \\
\hline Error & 24 & ns & ns & ns & ns \\
\hline
\end{tabular}

were placed on plates and watered daily. Symptoms were observed five weeks after sowing.

\section{Results and discussion}

Oat cultivars differed significantly in the percentage of plants expressing disease symptoms in 1994 (Table 2). The naked oat cv. Salomon showed the most severe foliar symptoms (up to $60 \%$ of plants showed symptoms). The dwarf cv. $\mathrm{Pal}$, conventional cv. Virma, and the landrace Jalostettu maatiainen were least affected (15-25\%), whereas the conventional cv. Salo was intermediately affected $(30 \%)$. The $\mathrm{N}$ fertilizer application rate had no effect on symptom severity measured at the end of growth period. Comparison of grain yields from the infected plots with those of the control plots indicated that the more severe foliar symptoms were not associated with higher yield reduction (Table 3 ). For example, the highest yield loss was recorded in the dwarf cultivar (56\%), whereas the smallest yield losses were observed in Salomon and Virma (35-
$37 \%$ ). Seedling emergence of Salomon was low in control plots compared to the infected plots, which resulted in slightly enhanced production of head-bearing tillers in the control. Taking this into consideration, the estimated crop loss of Salomon caused by the disease was about $50 \%$ in 1994.

In 1995, infection was more severe than in 1994. The intended control experiment, in which wheat had been grown as the previous crop, was fully diseased and no grain yield was obtained. In the infested test plot of 1995, the dwarf cv. Pal suffered most, and $65 \%$ of the plants died (Table 2). In the other lines up to $15 \%$ of the plants were killed. The average grain yield from the diseased plots was $1400 \mathrm{~kg} \mathrm{ha}^{-1}$, which was $60-70 \%$ less than the yields neighboring oat fields of the same cultivars in Viikki in 1995.

In all tested oat cultivars the reduction in grain yield caused by the disease was associated with changes in several morpho-physiological traits. Differences in duration of pre- and postanthesis phases between infected and control plots were marginal, but infection seemed to result in up to two days shorter grain-filling period especially at $0 \mathrm{~kg} \mathrm{~N} \mathrm{ha}^{-1}$ (Table 3 ). The ob- 


\section{AGRICULTURAL AND FOOD SCIENCE IN FINLAND}

Peltonen-Sainio, P. et al. Yield reduction caused by a soil-borne disease of oat

Table 3. Comparison of grain yield and characteristics of stands of naked (Salomon), dwarf (Pal), and conventional oat (mean across cvs. Virma, Salo, and Jalostettu maatiainen) between the field plots severely infected with Fusarium and the control plots in 1994 (across N fertilizer application rates).

\begin{tabular}{lcccccccc}
\hline Line & Trial\# & $\begin{array}{c}\text { Grain yield } \\
\left(\mathrm{kg} \mathrm{ha}^{-1}\right)\end{array}$ & $\begin{array}{c}\text { Seedlings } \\
\mathrm{m}^{-2} \\
(\mathrm{no})\end{array}$ & $\begin{array}{c}\text { Panicles } \\
\mathrm{m}^{-2} \\
\left(\mathrm{no}^{2}\right)\end{array}$ & $\begin{array}{c}\text { Heading } \\
(\mathrm{d})\end{array}$ & $\begin{array}{c}\text { Yellow } \\
\text { ripeness } \\
(\mathrm{d})\end{array}$ & $\begin{array}{c}\text { Grain- } \\
\text { filling } \\
\text { period (d) }\end{array}$ & $\begin{array}{c}\text { Plant } \\
\text { height } \\
(\mathrm{cm})\end{array}$ \\
\hline \multirow{2}{*}{ Salomon } & $\mathrm{C}$ & 2830 & 270 & 380 & 67 & 97 & 30 & 101 \\
& $\mathrm{~F}$ & 1760 & 390 & 430 & 67 & 98 & 31 & 100 \\
Pal & $\mathrm{C}$ & 5420 & 470 & 740 & 66 & 91 & 25 & 86 \\
& $\mathrm{~F}$ & 2400 & 510 & 590 & 65 & 92 & 27 & 78 \\
\multirow{5}{*}{ Conventional } & $\mathrm{C}$ & 5720 & 470 & 500 & 67 & 94 & 27 & 100 \\
& $\mathrm{~F}$ & 3250 & 510 & 560 & 67 & 96 & 29 & 99 \\
. \pm E. & $\mathrm{C}$ & 300 & 20 & 30 & $<1$ & $<1$ & $<1$ & 2 \\
& $\mathrm{~F}$ & 160 & 20 & 20 & $<1$ & $<1$ & $<1$ & 3 \\
\hline
\end{tabular}

\# C, control; F, experiment with severe Fusarium infection

servations on retarded growth in the field were verified by the yield component analysis which indicated that, in general, infected plants had shorter straw $(\leq 9 \%)$, less phytomass per plant $(\leq 18 \%)$ due to both lower vegetative phytomass $(\leq 22 \%)$ and panicle weight $(\leq 20 \%)$ resulting in inconsistent differences in $\mathrm{HI}$, less grains per panicle $(\leq 21 \%)$ associated with higher single grain weight $(\leq 4 \%)$, and reduced panicle $(\leq 25 \%)$ and grain-filling rates $(\leq 7 \%)$ when compared with controls (Table 4). Nitrogen fertilizer application rate had no significant effect on symptom severity and the percentage of killed plants when measured at the end of the growth period, but the disease was first perceived in the unfertilized plots.

A total of 57 fungal isolates belonging to Alternaria spp., Botrytis spp., Cladosporium spp., Drechslera spp., Epicoccum spp., Fusarium spp., and Sclerotinia spp. were obtained from oat leaves infected in the field. Preliminary tests for pathogenicity carried out in Petri dishes indicated that only the isolates of Fusarium culmorum and $F$. sambucinum were pathogenic to cv. Salomon. Infected seedlings died and were fully covered by fungal mycelia 5 to 10 days after inoculation. No other fungi tested caused any symptoms. No Fusarium spp. were found in the seeds of cvs. Salomon and Pal. Pathogenicity tests carried out in the glasshouse showed that all three tested isolates of $F$. culmorum (one from each Jalostettu maatiainen, Salomon, and Pal) were highly pathogenic on Salomon, whereas only a few seedlings of Pal showed symptoms (Table 5). Symptoms were expressed as seedling death 10 to 15 days after planting, or as a death of roots but survival of the stem and leaves of the seedling up to 35 days. White mycelia were observed on the basal stems of several dead seedlings for which microscopical examination revealed conidia characteristic of Fusarium spp. The two tested isolates of $F$. sambucinum obtained on Pal caused little damage on Salomon and no symptoms in $\mathrm{Pal}$ in the glasshouse.

Severe foliar symptoms observed in oat in the field directed us to isolate fungi from leaves in this study. However, only few isolated fungi were pathogenic on oat seedlings under experimental conditions, as reported above, and all pathogenic isolates were $F$. culmorum or F sambucinum. On the other hand, the plants showing foliar symptoms in the field could not be pulled out from soil without breaking the stems at the crown, suggesting that roots and crown were rotten. Therefore, it is concluded that the observed growth reduction and death of oat plants 
Vol. 5 (1996): 475-483.

Table 4. Comparison of yield components of naked (cv. Salomon), dwarf (cv. Pal), and conventional oat (mean across cvs. Virma, Salo, and Jalostettu maatiainen) between the field plots severely infected with Fusarium and the control plots in 1994 (across $\mathrm{N}$ fertilizer application rates).

\begin{tabular}{|c|c|c|c|c|c|c|c|c|c|}
\hline Cultivar & Trial\# & $\begin{array}{c}\text { Phytomass } \\
\text { (g) }\end{array}$ & $\begin{array}{c}\text { Vegetative } \\
\text { phytomass } \\
\text { (g) }\end{array}$ & $\begin{array}{c}\text { Panicle } \\
\text { weight } \\
\text { (g) }\end{array}$ & $\begin{array}{l}\mathrm{HI} \\
(\%)\end{array}$ & $\begin{array}{c}\text { Single } \\
\text { grain } \\
\text { weight }(\mathrm{mg})\end{array}$ & $\begin{array}{c}\text { Grains } \\
\text { panicle }^{-1} \\
\text { (no.) }\end{array}$ & $\begin{array}{l}\text { PFR } \\
\mathrm{mg} \mathrm{d}^{-1}\end{array}$ & $\begin{array}{l}\text { GFR } \\
\mathrm{mg} \mathrm{d}^{-1}\end{array}$ \\
\hline \multirow[t]{2}{*}{ Salomon } & $\mathrm{C}$ & 2.69 & 1.63 & 1.06 & 39.4 & 23.5 & 45 & 36.0 & 0.81 \\
\hline & $\mathrm{F}$ & 2.39 & 1.42 & 0.97 & 40.3 & 24.2 & 40 & 31.4 & 0.78 \\
\hline \multirow[t]{2}{*}{ Pal } & $\mathrm{C}$ & 2.01 & 0.96 & 1.06 & 52.6 & 31.2 & 34 & 42.0 & 1.24 \\
\hline & $\mathrm{F}$ & 1.68 & 0.83 & 0.85 & 50.4 & 31.3 & 27 & 31.3 & 1.15 \\
\hline \multirow[t]{2}{*}{ Conventional } & $1 \mathrm{C}$ & 2.34 & 1.23 & 1.11 & 47.7 & 28.5 & 39 & 41.1 & 1.06 \\
\hline & $\mathrm{F}$ & 1.91 & 0.96 & 0.95 & 49.0 & 29.6 & 32 & 32.6 & 1.03 \\
\hline \multirow[t]{2}{*}{.$\pm \mathrm{E}}$. & $\mathrm{C}$ & 0.08 & 0.06 & 0.03 & 1.3 & 0.8 & 1 & 1.5 & 0.04 \\
\hline & $\mathrm{F}$ & 0.08 & 0.06 & 0.03 & 1.1 & 0.8 & 1 & 1.2 & 0.03 \\
\hline
\end{tabular}

\# C, control; F, experiment with severe Fusarium infection

was primarily due to the root and foot disease caused by soil-borne Fusarium, and the foliar symptoms were attributed to other fungi which were capable of infecting oat plants stressed due to the root and foot damage caused by Fusarium. This is supported by yield reduction being associated with the percentage of plants which died rather than severity of foliar symptoms. Furthermore, root rot but no foliar symptoms was observed in oat plants inoculated with Fusarium spp. in the glasshouse.

F. culmorum is known as a soil-borne pathogen which overwinters as chlamydospores in soil and plant debris (Cook 1968) and causes root and foot rot of wheat, barley, and conventional oat in Finland (Mäkelä 1975, Mäkelä and Parikka 1980) and worldwide (Cook 1968, reviewed by Harder and Haber 1992). However, little has been reported about its importance in naked and dwarf oat. According to Cook and Christen (1976), growth of $F$. culmorum is enhanced when elevated temperatures occur under drier growth conditions. On the other hand, such conditions are more stressful for plants. Thus, the dry and warm weather conditions which prevailed during July were quite favorable for the development of the severe foot and root rot outbreak in the oat field plots in 1994 and 1995. Accumula- tion of chlamydospores in soil in 1994 probably contributed to the more severe disease outbreak in the same fields in 1995. Also F. sambucinum may become more harmful under such weather conditions, even though the results from our study and previous studies (Rawlinson and Colhoun 1970, Mäkelä 1975, Mäkelä and Parikka 1980 ) indicate that it is less important than $F$. culmorum in oat. Both Fusarium spp. can be

Table 5. Pathogenicity of $F$. culmorum and F. sambucinum [isolated from the landrace, naked cultivar (Salomon), and dwarf cultivar ( $\mathrm{Pal})$ infected in the field] on the seedlings of Salomon and Pal grown in inoculated soil in the glasshouse. Symptoms were recorded five weeks after sowing the pre-germinated oat seeds in the infested soil.

\begin{tabular}{|c|c|c|c|c|}
\hline \multirow[t]{2}{*}{ Fungus } & \multirow[t]{2}{*}{ Isolate } & \multicolumn{3}{|c|}{$\begin{array}{l}\text { No. of dead seedlings or seed } \\
\text { lings with dead roots per total } \\
\text { no. of tested seedlings }\end{array}$} \\
\hline & & & Salomon & Pal \\
\hline \multirow[t]{3}{*}{ F. culmorum } & Landrace & \#25 & $8 / 8$ & $2 / 8$ \\
\hline & Salomon & \#32 & $6 / 9$ & $0 / 8$ \\
\hline & Pal \#45 & & $9 / 11$ & $1 / 11$ \\
\hline \multirow[t]{2}{*}{ F. sambucinum } & Pal \#50 & & $1 / 11$ & $0 / 11$ \\
\hline & Pal \#52 & & $0 / 8$ & $0 / 10$ \\
\hline Non-inoculated & & & $0 / 8$ & $0 / 8$ \\
\hline
\end{tabular}




\section{AGRICULTURAL AND FOOD SCIENCE IN FINLAND}

Peltonen-Sainio, P. et al. Yield reduction caused by a soil-borne disease of oat

seed-transmitted in oat (Uoti and Ylimäki 1974) but were not found in the seeds of naked and dwarf oat used for establishing experiments in this study. However, seeds harvested from the diseased test plots were not tested for the presence of fungi, and it remains to be determined whether Fusarium spp. can be seed-borne in naked and dwarf oat.

\section{References}

Cook, R.J. 1968. Fusarium root and foot rot of cereals in the Pacific Northwest. Phytopathology 58: 127-131.

- \& Christen, A.A. 1976. Growth of cereal root rot fungi as affected by temperature-water potential interactions. Phytopathology 66: 193-197.

Domsch, K.H., Gams, W. \& Anderson, T.-H. 1980a. Compendium of soil fungi. Vol. 1. Academic Press, London, UK. 859 p.

- , Gams, W. \& Anderson, T.-H. 1980b. Compendium of soil fungi. Vol. 2. Academic Press, London, UK. 405 p.

Harder, D.E. \& Haber, S. 1992. Oat diseases and pathologic techniques. In: Marshall, H.G. \& Sorrells, M.E. (eds.). Oat Science and Technology. American Society of Agronomy, Madison, Wisconsin, USA. p. 307-425.

MSTAT Development Team 1989. MSTAT User's Guide: A microcomputer program for the design, management, and analysis of agronomic research experiments. Michigan State University, East Lansing.

Mäkelä, K. 1975. Occurrence of foliicolous fungi on ce- reals in Finland in 1971-1973. Journal of the Scientific Agricultural Society of Finland 47: 245-269.

- \& Parikka, P. 1980. Root and foot rot diseases of cereals in southern Finland in 1975-1978. Annales Agriculturae Fenniae 19: 223-253.

Peltonen-Sainio, P. \& Karjalainen, R. 1990. Yield reduction of oat cultivars in relation to disease development caused by barley yellow dwarf virus. Journal of Agricultural Science in Finland 62: 265-273.

Rautapää, J. 1976. Population dynamics of cereal aphids and method of predicting population trends. Annales Agriculturae Fenniae 15: 272-293.

Rawlinson, C.J. \& Colhoun, J. 1970. Chemical treatment of cereal seed in relation to plant vigour and control of soil fungi. Annals of Applied Biology 65: 459-472. Uoti, J. \& Ylimäki, A. 1974. The occurrence of Fusarium species in cereal grain in Finland. Annales Agriculturae Fenniae 13: 5-17. 


\title{
AGRICULTURAL AND FOOD SCIENCE IN FINLAND
}

Vol. 5 (1996): 475-483.

\section{SELOSTUS}

\section{Maalevintäinen juuri- ja tyvitauti alensi kuorettoman kauran, kääpiökauran ja yleisesti viljellyn kauran satoa}

\author{
Pirjo Peltonen-Sainio, Jari P.T. Valkonen ja Hilkka Koponen \\ Helsingin yliopisto
}

Kauran kasvu hidastui ja sadontuottokyky heikkeni tautiepidemian seurauksena Viikin koetilan pelloilla vuosina 1994 ja 1995. Erityisesti kasvuston alalehdissä ilmeni harmaanruskeita laikkuja, ja vuonna 1995 osa kasvustosta kuihtui. Oireellisten kasvien juuret ja varren tyvi olivat lahot. Taudinkuvaan kuului lisäksi hidas kasvuunlähtö ja hidas kuiva-aineen kertyminen niin vegetatiivisiin kasvinosiin kuin itse sato-osaankin.

Koesarjassa mukana olleista kauratyypeistä erityisesti Minnesotassa jalostettu kääpiökaura (Pal) sekä kuoreton kauralajike (Salomon) olivat voimakkaasti oireellisia. Kääpiökauran kasvustosta jopa $65 \%$ kuoli ennenaikaisesti vuonna 1995. Pitkäkortisen maatiaisen (Jalostettu maatiainen) ja modernien lajikkeiden (Virma ja Salo) oireet olivat voimakkuu- deltaan lieviä tai keskimääräisiä. Satotappiot aiheutuivat pääosin alhaisesta jyvämäärästä. Sen sijaan saastuneiden yksilöiden jyvien keskipaino saattoi jopa nousta.

Oireellisista alalehdistä eristettiin kaikkiaan 57 sieni-isolaattia, joista kaksi Fusarium-lajia olivat patogeenisia laboratorio- ja kasvihuonekokeissa ( $F$. culmorum ja $F$. sambucinum). Poikkeuksellisen lämmin ja kuiva keskikesä vuosina 1994 ja 1995 ilmeisesti edisti maalevintäisten Fusarium-lajien aiheuttaman juuri- ja tyvitaudin puhkeamista, mikä puolestaan aiheutti satotappiot. Alun pitäen huomion kohteena olleet lehtioireet lienevät johtuneet muista sienistä, jotka tartuttivat heikentyneiden kasvien lehtiä, eivätkä siten liene olleet satotappioiden kannalta keskeisiä. 